\title{
Short Communication: \\ The presence of Bull shark Carcharhinus leucas (Elasmobranchii: Carcharhinidae) in the fresh waters of Sumatra, Indonesia
}

\author{
VERYL HASAN ${ }^{1,2, \vartheta}$, MAHENO SRI WIDODO ${ }^{3, \vee \varphi}$ \\ ${ }^{1}$ Department of Fish Health Management and Aquaculture, Faculty of Fisheries and Marine Science, Universitas Airlangga. Jl. Dr. Ir. Sukarno, Surabaya \\ 60115, East Java, Indonesia. Tel.: +62-31-315911541, Fax.: +62-31-5965741, "email: veryl.hasan@ fpk.unair.ac.id \\ ${ }^{2}$ Division of Zoology, Generasi Biologi Indonesia Foundation. Jl. Swadaya Barat No. 4, Gresik 61171, East Java, Indonesia \\ ${ }^{3}$ Department of Aquaculture, Faculty of Fisheries and Marine Science, Universitas Brawijaya. Jl. Veteran, Malang 65145, East Java, Indonesia. \\ Tel.: +62-341-553512, Fax.: +62-341-556837, ${ }^{\vee v}$ email: maheno2019@gmail.com
}

Manuscript received: 15 July 2020. Revision accepted: 30 August 2020.

\begin{abstract}
Hasan V, Widodo MS. 2020. Short Communication: The presence of Bull shark Carcharhinus leucas (Elasmobranchii: Carcharhinidae) in the fresh waters of Sumatra, Indonesia. Biodiversitas 21: 4433-4439. A single subadult specimen of Bull shark Carcharhinus leucas was photographed and captured by local fisherman using casting net on June 2020 in the upper Indragiri River, Riau Province, Indonesia. Carcharhinus leucas are one of only a few species of elasmobranchs that live in both marine and freshwater environments. This species currently listed as a near-threatened species based on the IUCN Red List Status. Singel specimen identified as $C$. leucas by the coloration of fresh specimen: white belly and greyish back, first dorsal fin high, tip of second dorsal and caudal fins black. Meristic characters measurement results as follows: total length $102 \mathrm{~cm}$; fork length $86.3 \mathrm{~cm}$; preanal length $65.1 \mathrm{~cm}$; pre pelvic length $51.9 \mathrm{~cm}$; pre pectoral length $22.5 \mathrm{~cm}$; pre-orbital length $8.3 \mathrm{~cm}$; head length $25 \mathrm{~cm}$; pre-first dorsal length $29.4 \mathrm{~cm}$; pre-second dorsal length $56 \mathrm{~cm}$, and pre-caudal length $78.1 \mathrm{~cm}$. This photo is considered as the third record from freshwaters of Sumatra after in the Batang Hari River, Jambi Province in 1997, and in the Musi River, South Sumatra Province in 2019. The photographic records indicate that a single specimen of $C$. leucas was found in the upper Indragiri River recorded more than $150 \mathrm{~km}$ inland. These results enhanced the understanding of $C$. leucas distribution in Sumatra freshwaters. Monitoring is needed to assess the possibility of the importance of the upper Indragiri River as a migration route, nursery, and growth ground of $C$. leucas. Studying small scale habitat use of $C$. leucas is challenged by their preferred habitats in freshwaters environments with fast-changing environmental conditions. Water conditions in the upper Indragiri River, namely salinity $0 \%$, temperature $25-27^{\circ} \mathrm{C}$, dissolved oxygen $3.9-11.1 \mathrm{mg} / \mathrm{l}$, are ideal for $A$. leucas habitat.
\end{abstract}

Keywords: Biogeography, Chondrichthyes, distribution, near threatened

\section{INTRODUCTION}

The Bull shark Carcharhinus leucas (Müller \& Henle, 1839) is one of the few elasmobranchs that is truly euryhaline and is a common species that occurs in nearshore in estuarine and coastal riverine environments and is wide-spread along the continental coast of all subtropical and tropical seas as well as numerous lakes and rivers, rarely found deeper than $3080 \mathrm{~m}$ (Kumar et al. 2018; Wagner et al. 2013). It has been found $4200 \mathrm{~km}$ in the upper Amazon River, Peru South America (Myers 1952); $2800 \mathrm{~km}$ in the upper the Mississippi River in Illinois, North America (Thomerson et al. 1977); $1120 \mathrm{~km}$ in the upper Zambezi River, South Africa (Bass et al. 1973), and has been recorded navigating rapids as it moves between nearshore coastal habitat and Cocibolca Lake, Nicaragua Central America (Thorson 1971). The adaptation of $C$. leucas to freshwaters has occurred independently in the evolution of euryhaline shark (Lucifora et al. 2015). However, the factors affecting the poor penetration of euryhaline shark into upper river are currently unknown. An important consideration might be the high urea requirement of many proteins in marine elasmobranch (Ballantyne and Robinson 2010; Larsen et al. 2019).

Carcharhinus leucas are top carnivore and their longterm presence in an urban or natural habitat could therefore be an indicator of the quality of that ecosystem conditions and available prey are at levels suitable to sustaining a local population of this species (Bernard et al. 2016; Matich and Heithaus 2016). C. leucas can grow to a total length of about $340400 \mathrm{~cm}$ (Mcord and Lambert 2009). Like most of the species in the genus Carcharhinus, C. leucas is plain grey above, with a pale to white underbelly. They have broad, rounded snouts and small eyes (Compagno et al. 2005; Ebert et al. (2013). C. leucas is a generalist feeder, although brackish water fish, Mullets, and several brackish water fish, is believed to be a significant part of the diet in subadults and juveniles, although, they are opportunistic feeders targeting bony fishes, invertebrates, sharks, turtles, reptiles, birds, dolphins, semi-aquatic and terrestrial mammals (Werry 2010; Daly et al. 2013; Tillett et al. 2014).

Although the knowledge about $C$. leucas and its distribution has increased over the past decades, the borders and the full range of it reach in some regions unclear, especially in the inland waters (Compagno et al. 
2002; Drymon et al. 2014). C. leucas is a large coastal apex predator that is globally distributed in warm temperate waters, including Indonesian freshwaters, and the only known records of this species were found in Sumatra (Tan and Lim 1998) and Borneo (Iqbal et al. 2019a). In Sumatra, C. leucas was recorded in Batang Hari River, Jambi Province in 1997 (Tan and Lim 1998), and Musi River, South Sumatra Province in 2019 (Iqbal et al. 2019b). In this paper, we report the existence of $C$. leucas in the upper Indragiri River, Riau Province, Indonesia which documents an extension of the known distribution range for this species. The movement and migration patterns of C. leucas in time and space are fundamental to the study of its habitat ecology, interpreting the influence of urban activities on the species and to the design of effective resource management and conservation (Shuter et al. 2010; Daly et al. 2014).

\section{MATERIALS AND METHODS}

\section{Sampling site}

The site is in the upper Indragiri River, Kelayang Subdistrict, Indragiri Hulu District, Riau Province, Sumatra Island, Indonesia $\left(0^{\circ} 31^{\prime} 53 " \mathrm{~S} ; 102^{\circ} 05^{\prime} 07^{\prime \prime} \mathrm{E}\right)$, more than 150 $\mathrm{km}$ distance from the mouth of the river, located in remote and palm plantation areas, near Tesso Nilo National Park (TNTN). The Indragiri River is the main river in Sumatra, Riau Province. It is formed from the union of the Sinamar River and Ombilin River, and empties into the west coast of Sumatra, Malacca Strait. In the Kuantan Singingi Regency, this river is called Kuantan River. The river flows to the eastern area of Sumatra with predominantly tropical rainforest. The annual average temperature in the area is around $22-24^{\circ} \mathrm{C}$ and rainfall is around $345-2757 \mathrm{~mm}$ (Peel et al. 2007). The water quality parameters were determined directly on-site one day after capture.

\section{Fish collection}

Fish collection could be freely carried out without requiring special permits. We collected a single specimen (Figure 1) using casting net assisted by local fishermen on 25 June 2020. The structure of net is a conical shape, where gill is attached in bottom side maintaining a specific difference and made pockets joining gill attached line to upper body of the net. This net is encircling in nature and gradually wider from top, fishermen throw the net on water bodies and fishes are get trapped in pockets (Dutta et al. 2016).

\section{Fish identification}

-The specimen was documented and photographed, although no voucher specimen was retained because the fish was too large to be stored and we did not have enough space in the laboratory. Morphometric measurements of the single specimen were analyzed following Compagno and Niem (1998), and Ebert et al. (2013). The determined morphometric characters include the total length, fork length, pre anal length, pre pelvic length, pre pectoral length, pre orbital length, head length, pre first dorsal length, pre-second dorsal length, and pre caudal length (Figure 1).

\section{RESULTS AND DISCUSSION}

\section{New record}

Indonesia: Sumatra Island: Riau Province: Kelayang subdistrict: Indragiri Hulu district: upper Indragiri River: slow-flowing stream: $\left(0^{\circ} 31^{\prime} 53 " \mathrm{~S} ; 102^{\circ} 05^{\prime} 07^{\prime \prime E}\right)$ (Figure $z$ 3), 25 June 2020, single specimen $102 \mathrm{~cm}$, subadult, photographed.

\section{Scientific classification}

Classification of the species is as follows: Kingdom: Animalia, Phylum: Chordata, Class: Chondrichthyes, Subclass: Elasmobranchii, Order: Carcharhiniformes, Family: Carcharhinidae, Genus: Carcharhinus, Species: Carcharhinus leucas (Müller \& Henle, 1839) (Figure 2). Synonymy: Pterolamiops budkeri (Fourmanoir, 1961); Pterolamiops magnipinnis (Smith, 1958); Carcharias insularum (Snyder, 1904); Carcharias (Prionodon) obtusus (Garman, 1881); Squalus (Carcharias) maou (Lesson, 1830)

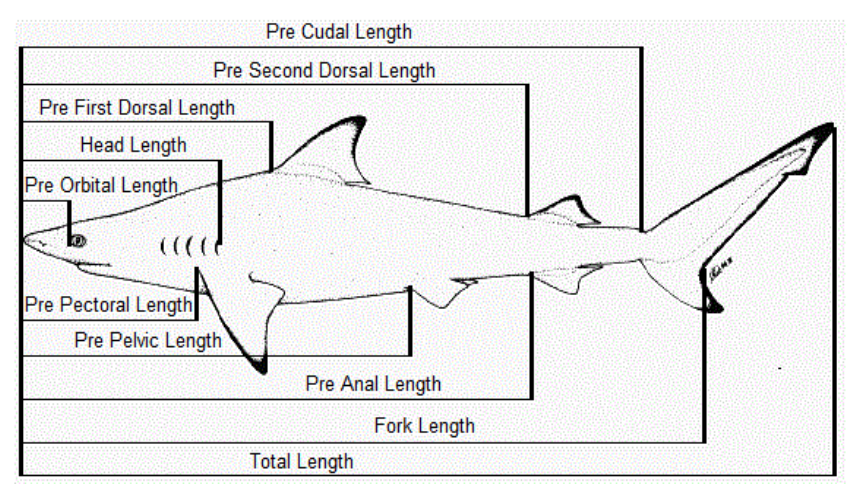

Figure 1. Morphometric measurements of Carcharhinus leucas according to Compagno (1984)

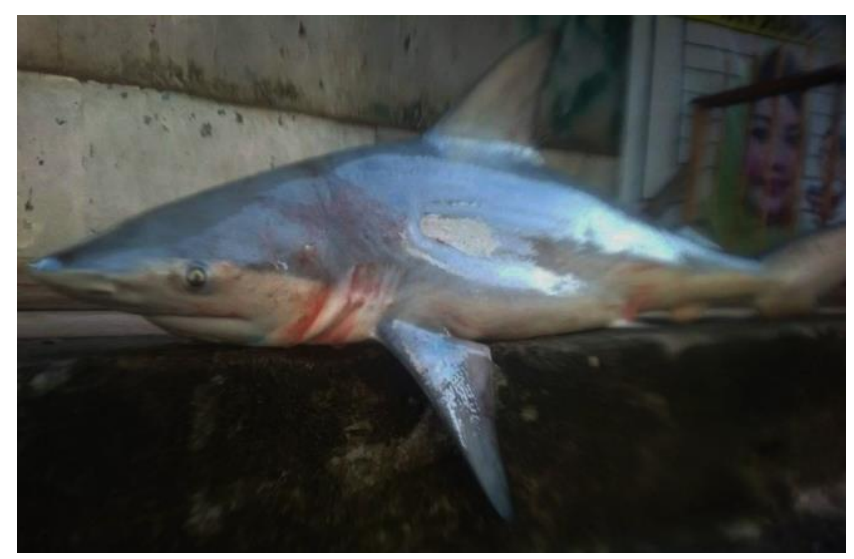

Figure 2. A specimen of Carcharhinus $(102 \mathrm{~cm})$, which was captured by local fishermen in the upper Indragiri River at Kelayang Subdistrict, Indragiri Hulu District, Riau Province, Indonesia 


\section{Morphological characters of Carcharhinus leucas captured from upper Indragiri River}

Carcharhinus leucas collected in the upper Indragiri River has features of Carcharhinidae family: short and broad snout; large, elongated, and arched mouth; small eyes on the side of the head; two dorsal fins: the first dorsal fin is moderately large, much shorter than the caudal fin, and its base is located over the interspace between pectoral and ventral fin bases; broad pectoral fins, with narrow pointed tips. This fish is identified as C. leucas by the coloration of fresh specimens: white belly and greyish back, high first dorsal fin, the black coloration on the tip of the second dorsal, and caudal fins (Fig. 2). Morphometric characters of this specimen of C. leucas are given in Table 1.

Table 1. Morphometric of a single specimen of Carcharhinus leucas, from upper Indragiri River

\begin{tabular}{lc}
\hline \multicolumn{1}{c}{ Character } & Morphometric $(\mathbf{c m})$ \\
\hline Total length & 102 \\
Fork length & 86.3 \\
Pre anal length & 65.1 \\
Pre pelvic length & 51.9 \\
Pre pectoral length & 22.5 \\
Pre orbital length & 8.3 \\
Head length & 25 \\
Pre first dorsal length & 29.4 \\
Pre second dorsal length & 56 \\
Pre caudal length & 78.1 \\
\hline
\end{tabular}

\section{Contemporary records and its habitat}

The migratory patterns and drivers of $C$. leucas are yet to be thoroughly understood. C. leucas have been reported to migrate towards warmer latitudes during the austral winter in the western Indian Ocean (Daly et al. 2014; Lea et al. 2015; Pirog et al. 2015). The discovery of C. leucas in the upper Indragiri River is a new record of this species for this location. There are several studies on Chondrichthyes in Indonesian freshwaters which are sometimes limited to a single river. As in the case with $C$. leucas records in freshwaters of Sumatra, Tan and Lim (1998) have recorded C. leucas in Batang Hari River, Jambi Province, and then Iqbal et al. (2019b) added that $C$. leucas has also recorded in the Musi River, South Sumatra Province (Figure 3). The presence of $C$. leucas in the upper Indragiri River as a sign that the ecosystems in the river are still quite good. Among other biological topics, the new record of endangered fish is an important contribution to understanding species diversity and biogeography. As reported in this paper, the new record of $C$. leucas has helped to improve the knowledge of the species as it extends the distribution range of the species further north. In the future, the data collection using assisted by local fishermen is needed to assess the occurrence of $C$. leucas and evaluate the importance of basin systems in freshwaters of Sumatra as migration route, nursery, and growth ground.

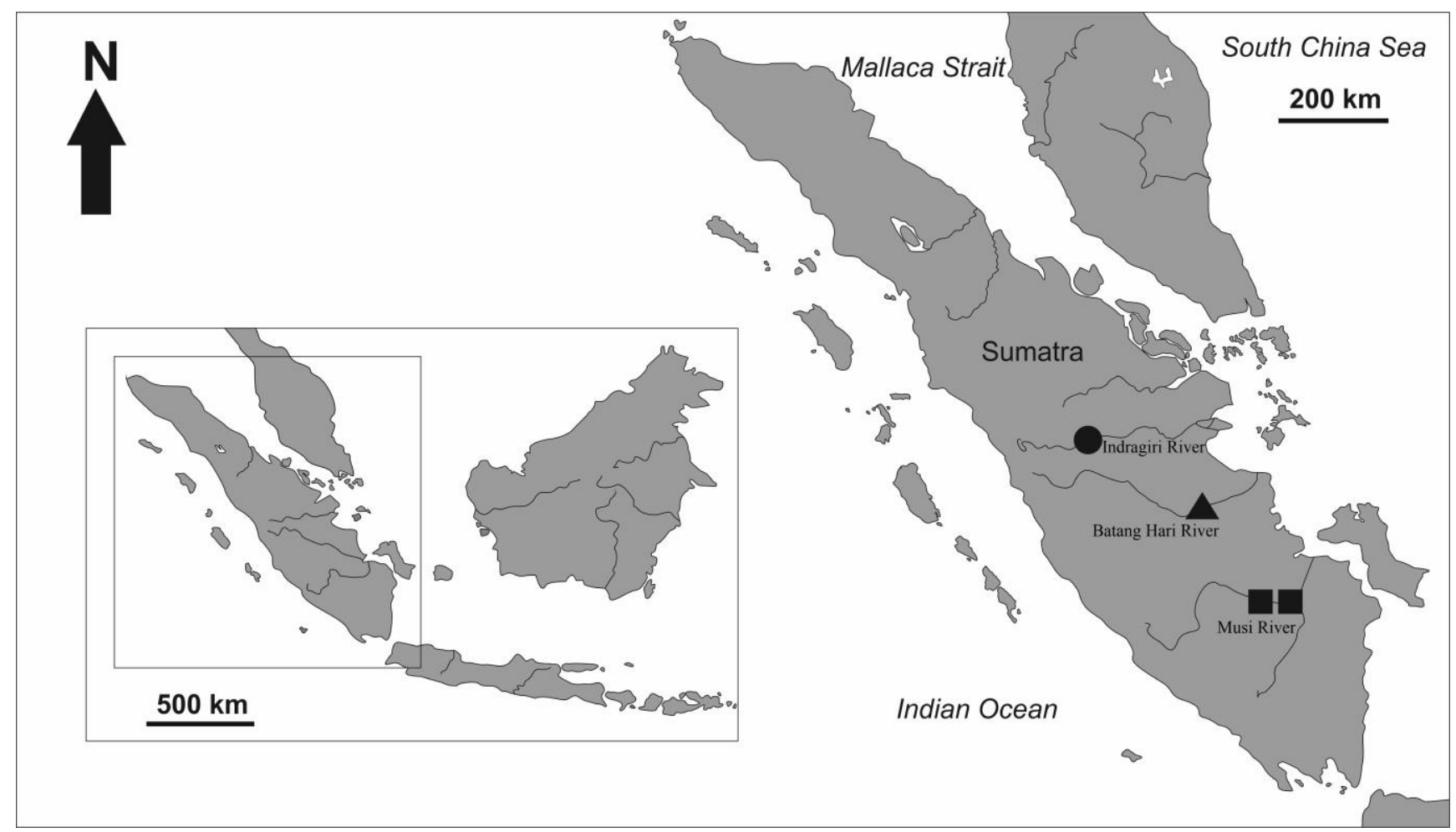

Figure 3. Location of known C. leucas collected in freshwaters of Sumatra, Indonesia. The black triangle shows the previous record from Batang Hari River, Jambi Province in 1997; the black squares show the previous record from Musi River, South Sumatra Province in 2019; and the black circle shows the recent record from upper Indragiri River, Riau Province in 2020 
The life history of C. leucas is strongly dependent on brackish waters. This species has the osmoregulatory plasticity to acclimate the marine and their preferences for the inland waters of lakes or rivers where salinity is low, therefore, likely to be for avoiding top carnivore and increasing of prey abundance rather than because of a physiological constraint (Pillans and Franklin 2004; O'Connell et al. 2007). Migrations of C. leucas may also be directly related to changes in water condition, specifically salinity, to decrease energy expended for osmoregulation (Glaus et al. 2019; Reilly 2011). Osmoregulation in C. leucas is achieved through the control and integration of various organs such as the liver and kidney in response to salinity changes. However, little is known regarding the mechanisms of ion transport in the gills of euryhaline C. leucas and how they are affected by osmoregulatory challenges (Hazon et al. 2003; Evans et al. 2004)

Estuaries are biologically diverse and productive ecosystems that provide essential habitats for many fauna and flora including avertebrata, finfish, reptile, and amphibian (Paighambari et al. 2017; Abrantes et al. 2019). Characterized by shallow water and intertidal areas, including mangrove forests, swamps, saltmarsh, seagrass, intertidal mudflats, and shallow sub-tidal habitats, they are transitional habitats between land and water and freshwater and marine environments (Thomas 2017; Dubuc et al. 2019). Carcharhinus leucas and their prey that have life cycles closely tied to river and estuarine environments are likely to be directly influenced by large-scale shifts in flood events and rainfall (Haig et al. 2018; Bangley et al. 2018; Pillans et al. 2020).

Several environmental factors may interact to define elasmobranch movement patterns, including water temperature (Matich and Heithaus, 2012; Smoothey et al. 2016) dissolved oxygen (Nosal et al. 2016; Galván-Magaña 2019), and salinity (Froeschke 2010; Hyatt et al. 2018; Curtis et al. 2011). Water quality parameters may also play an indirect role in the $C$. leucas movement due to the influence of fluctuating conditions on the distribution of prey species. Water conditions in the upper Indragiri River, namely salinity $1.5 \%$, temperature $25-27^{\circ} \mathrm{C}$, dissolved oxygen 3.9-11.1 mg/l, are ideal for A. leucas habitat (Drymon et al. 2014, Hyatt et al. 2017). Future research incorporating long-term trends with these short-term results would help form a more complete understanding of the degree to which water quality parameters influence movement of this species. For example, the temperature is more likely to have a role in $C$. leucas presence over a longer period, showing seasonal variation (Carlson et al 2010; Werry et al. 2018).

\section{Bull shark-human interaction in Sumatra}

Although C. leucas attacks occur infrequently, they often have serious consequences for those involved, invoke a dramatic emotional response from the general public, and therefore attract a high level of media interest (West 2011). Carcharhinus leucas are historically responsible for at least 100 unprovoked attacks on humans around the world, 27 of which have been fatal. Its proclivity for freshwater, large size, abundance, and proximity to human populations, particularly in the tropics, makes it a potential threat (ISAF 2008; Florida Museum 2018). In waters of Sumatra, there is no official record of C. leucas attacks on humans.

\section{Utilization of Carcharhinus leucas in Sumatra}

Carcharhinus leucas is not the main commodity of capture fisheries in Sumatra because the number of individuals entering into freshwaters of Sumatra is very rare. There is no official record of how many C. leucas are caught because these fish are not a targeted species in Indonesia's commercial fisheries. The Indonesian government needs to strictly prohibit the practice of catching sharks, especially $C$. leucas. If the fish are caught, immediately release again into the waters so that the population of C. leucas is maintained in Indonesian waters.

Although $C$. leucas are not normally targeted, but are commonly taken in commercial and recreational fisheries for their meat and fins. In some areas such as the Caribbean Sea, C. leucas is still a fisheries commodity (Dulvy et al. 2014; Md-Zain et al. 2018). It is caught mainly with, fishnet, longlines, hook-and-line gear and utilized fresh, smoked, or fresh-frozen for human consumption; its fins for traditional medicine, its skin is used for leather, and its liver oilfish, which is extracted for vitamins, carcasses are also rendered for fishmeal (Davidson et al. 2016; Zainuddin et al. 2017). However, shark fisheries have no food security role in several countries. Fins have low nutritional value and shark meat consumption is discouraged for its high concentration of heavy metals (Nicolaus 2016; Barcia et al. 2020).

\section{Conservation status}

The range of movement of $C$. leucas can therefore determine the species potential interaction with fisheries and their vulnerability to these pressures (O'Connell et al. 2014; Laurrabaquio-A, 2019). Because it lives in the inshore, estuarine, and freshwater region close to human populations, it is vulnerable to the impact of human activity. Carcharhinus leucas is not currently legally protected in any part of its range. Further research is necessary to better characterize its ecological, biological, and fisheries significance (Heupel and Simpfendorfer 2008; Simpfendorfer and Burgess 2009).

Carcharhinus leucas are designated as Near Threatened (NT) by the IUCN due to the close proximity of critical habitats to anthropogenic influences (Simpfendorfer and Burgess 2009). The consequences to freshwater and marine ecosystem have recently become apparent with the profound global declines large pelagic fish population, including C. leucas (Ferretti et al. 2010; Luciflora et al. 2011; Arthington et al. 2016;). Despite their ecological significance, however, populations of many species of sharks are declining on a global scale, mainly due to illegal and unsustainable fishing practices (Temple et al. 2017; Yulianto et al. 2018).

Estuarine sharks such as C. leucas are potentially highly vulnerable to urban habitat modification, as they are subject to not just the same biological constraints as their oceanic counterparts but also additional habitat constraints 
not faced by their stenohaline relatives (Werry et al. 2012; Niella et al. 2017). Estuarine and river habitats have more limited volume and their physicochemical properties vary widely (Potter et al. 2015; Ceccarelli et al. 2013). Because of their association with coastal, estuarine, freshwater environments, C. leucas are also susceptible to habitat degradation and the influence of climate change (Chin et al. 2010; Pistevos et al. 2015)

\section{ACKNOWLEDGEMENTS}

We thank the editor and reviewers for their insightful comments, Zoology Division of Generasi Biologi Indonesia Foundation, Asief Abdi, April, and local fishermen as a field guide, and the Ministry of Finance of Republic of Indonesia as the funding for research (no. 20160221035555).

\section{REFERENCES}

Abrantes KG, Sheaves M, Fries J. 2019. Estimating the value of tropical coastal wetland habitats to fisheries: Caveats and assumptions. PLoS ONE 14 (4): e0215350. DOI: 10.1371/journal.pone.0215350.

Arthington AH, Dulvy NK, Gladstone W, Winfield IJ. 2016. Fish conservation in freshwater and marine realms: status, threats and management. Aquat Conserv Mar Freshw Ecosyst 26 (5): 838-857.

Ballantyne JS, Robinson JW. 2010. Freshwater elasmobranchs: a review of their physiology and biochemistry. J Compar Physiol B 180 (4): 475-493.

Bangley CW, Paramore L, Shiffman DS, et al. 2018. Increased abundance and nursery habitat use of the Bull shark (Carcharhinus leucas) in response to a changing environment in a warm-temperate estuary. Sci Rep 8: 6018. DOI: 10.1038/s41598-018-24510-z.

Bass AJ, D'Aubrey JD, Kitnasamy N. 1973. Sharks of the east coast of Southern Africa. I. Genus Carcharhinus (Carcharhinidae). Investigational Report 33. Oceanographic Research Institute, Durban.

Bernard AM, Feldheim KA, Heithaus MR, et al. 2016. Global population genetic dynamics of a highly migratory, apex predator shark. Mol Ecol 25 (21): 5312-5329.

Brown S, Reid D, Rogan E. 2014. Characteristics of fishing operations, environment and life history contributing to small cetacean bycatch in the Northeast Atlantic. PLoS ONE 9 (8): e104468. DOI: 10.1371/journal.pone.0104468.

Brunnschweiler JM, Baensch H. 2011. Seasonal and long-term changes in relative abundance of bull sharks from a tourist shark feeding site in Fiji. PLoS One 6: e16597. DOI: 10.1371/journal.pone.0016597.

Burns NM, Bailey DM, Wright PJ (2019) A method to improve fishing selectivity through age targeted fishing using life stage distribution modelling. PLoS ONE 14 (4): e0214459. DOI: 10.1371/journal.pone.0214459.

Carlson JK, Ribera MM, Conrath CL, et al. 2010. Habitat use and movement patterns of bull sharks Carcharhinus leucas determined using pop-up satellite archival tags. J Fish Biol 77: 661-675.

Ceccarelli DM, Frisch AJ, Graham NAJ, et al. 2013. Habitat partitioning and vulnerability of sharks in the Great Barrier Reef Marine Park. Rev Fish Biol Fish 24 (1): 169-197.

Chapman BK, McPhee D. 2016. Global shark attacks hot spots: Identifying underlying factors behind increased unprovoked shark bite incidence Ocean Coast Manag 133: 72-84.

Chin A, Kyne PM, Walker TI et al. 2010. An integrated risk assessment for climate change: analysing the vulnerability of sharks and rays on Australia's Great Barrier Reef. Global Ch Biol 16 (7): 1936-1953.

Collette BB, Carpenter KE, Polidoro BA, et al. 2011. High value and long life-double jeopardy for tunas and billfishes. Science 333: 291 292.

Compagno L, Dando M, Fowler S. 2005. A Field Guide to the sharks of the world. Princeton University Press, New Jersey.
Compagno LJV. 1984. FAO Species Catalogue. Vol. 4. Sharks of the world. An annotated and illustrated catalogue of shark species known to date. Part 2-Carcharhiniformes. FAO Fish Synop 125 (4/2): 251655. Rome: FAO.

Compagno LJV. 1998. Sharks. In: K. E. Carpenter, V.H. Niem (Eds), Species identification Guide for Fishery Purposes. The living Marine Resources of the Western Central Pacific. Vol.2. Cephalopods, Crustaceans, Holothurians, and Sharks. FAO, Rome.

Compagno LJV. 2002. Freshwater and estuarine elasmobranch surveys in the Indo-Pacific Region: threats, distribution and speciation. In: Fowler, S.L., Reed, T.M. \& Dipper, F.A. (Eds), Elasmobranch Biodiversity, conservation and management: Proceedings of the International seminar and workshop, Sabah, Malaysia, July 1997. IUCN SSC Shark Specialist Group, Switzerland and Cambridge.

Curtis TH, Adams DH, Burgess GH. 2011. Seasonal distribution and habitat associations of bull sharks in the Indian River Lagoon, Florida: A 30-year synthesis. Trans Amer Fish Soc 140: 1213-1226.

Daly R, Smale MJ, Cowley PD, et al. 2014. Residency Patterns and migration dynamics of adult Bull sharks (Carcharhinus leucas) on the East Coast of Southern Africa. PLoS ONE 9 (10): e109357. DOI: 10.1371/journal.pone.0109357.

Daly R., Froneman PW, Smale MJ. 2013. Comparative Feeding Ecology of Bull Sharks (Carcharhinus leucas) in the Coastal Waters of the Southwest Indian Ocean Inferred from Stable Isotope Analysis. PLoS ONE 8 (10): e78229. DOI: 10.1371/journal.pone.0078229.

Davidson LNK, Krawchuk MA, Dulvy NK. 2016. Why have global shark and ray landings declined: Improved management or overfishing? Fish Fish 17 (2): 438-458.

Drymon JM, Ajemian MJ, Powers SP. 2014. Distribution and dynamic habitat use of young Bull sharks Carcharhinus leucas in a highly stratified Northern Gulf of Mexico Estuary. PLoS ONE 9 (5): e97124.

Dubuc A, Waltham NJ, Baker R, et al. 2019. Patterns of fish utilisation in a tropical Indo-Pacific mangrove-coral seascape, New Caledonia. PLoS ONE 14 (4): e0207168. DOI: 10.1371/journal.pone.0207168.

Dulvy NK, Fowler SL, Musick JA, et al. 2014. Extinction risk and conservation of the world's sharks and rays. eLife 3 (e00590): E00590. DOI: $10.7554 /$ LLife.00590.

Dutta B, Das N, Kar D. 2016. The fish catching devices with theirefficacy and cost-benefit analysis in the Towkak river in Assam and Nagaland, India. Fish Aquac J 7: 156.

Ebert D, Fowler S, Compagno L. 2013 Sharks of the world, a fully illustrated guide. Wild Nature Press, Plymouth.

Evans DH, Piermarini PM, Choe KP. 2004. Homeostasis: osmoregulation, $\mathrm{pH}$ regulation, and nitrogen excretion. In: Carrier JC, Musick J, Heithaus MR (eds) Biology of sharks and their relatives. CRC Press, Boca Raton.

Ferretti F, Jorgensen S, Chapple TK et al. 2015. Reconciling predator conservation with public safety. Front Ecol Environ 13 (8): 412-417.

Ferretti F, Worm B, Britten GL, et al. 2010. Patterns and ecosystem consequences of shark declines in the ocean. Ecol Lett 13 (8): 105571.

Florida $\quad$ Museum. 2018. Carcharhinus leucas. www.floridamuseum.ufl.edu

Froeschke J, Stunz G, Wildhaber, M. 2010. Environmental influences on the occurrence of coastal sharks in estuarine waters. Mar Ecol Prog Ser 407: 279-292.

Galván-Magaña F, Castillo-Geniz JL, Hoyos-Padilla M, et al. 2019. Shark ecology, the role of the apex predator and current conservation status. Sharks in Mexico: Research and Conservation Part A. Elsevier, Amsterdam.

Garcia Barcia L, Argiro J, Babcock EA, et al. 2020. Mercury and arsenic in processed fins from nine of the most traded shark species in the Hong Kong and China dried seafood markets: The potential health risks of shark fin soup. Mar Pollut Bull 157: 111-281.

Glaus KBJ, Brunnschweiler JM, Piovano S et al. 2019. Essential waters: Young bull sharks in Fiji's largest riverine system. Ecol Evol 9: 75747585.

Haig JA, Lambert G I, Sumpton WD et al. 2018. Habitat features influence catch rates of near-shore bull shark (Carcharhinus leucas) in the Queensland Shark Control Program, Australia 1996-2012. Estuar Coast Shelf Sci200: 289-300.

Hazon N, Wells A, Pillans RD, Good JP, Anderson WG, Franklin CE. 2003. Urea based osmoregulation and endocrine control in elasmobranch fish with special reference to euryhalinity. Compar Biochem Physiol B 136: 685-700. 
Hyatt MW, Anderson PA, O'Donnell PM. 2018. Influence of Temperature, Salinity, and Dissolved Oxygen on the Stress Response of Bull (Carcharhinus leucas) and Bonnethead (Sphyrna tiburo) Sharks after Capture and Handling. J Coast Res 344: 818-827.

Iqbal M, Nurnawati E, Setiawan A et al. 2019a. First photographic inland records of bull shark Carcharhinus leucas (Carcharhiniformes: Carcharhinidae) in Sumatran waters, Indonesia. Ecologica Montenegrina 22: 171-176.

Iqbal M, Setiawan M, Yustian I. 2019b. First inland record of bull shark Carcharhinus leucas (Carcharhiniformes: Carcharhinidae) in Indonesian Borneo. Ecologica Montenegrina 24: 52-57.

ISAF. 2018. International Shark Attack File. www.flmnh.ufl.edu.

Kolding J, van Zwieten P. 2014. Sustainable fishing of inland waters. J Limnol 73 (s1): 132-148.

Kumar RR., Venu S, Akhilesh KV, et al. 2018. First report of four deepsea chondrichthyans (Elasmobranchii and Holocephali) from Andaman waters, India with an updated checklist from the region. Acta Ichthyologica et Piscatoria 48 (3): 289-301.

Larsen ME, Abel DC, Crane DP, et al. 2019. Unique osmoregulatory morphology in primitive sharks: an intermediate state between holocephalan and derived shark secretory morphology. J Fish Biol 2019: 1-11. DOI: $10.1111 / \mathrm{jfb} .14139$.

Laurrabaquio-A SN, Islas-Villanueva V, Adams DH, et al. 2019. Genetic evidence for regional philopatry of the Bull Shark (Carcharhinus leucas), to nursery areas in estuaries of the Gulf of Mexico and western North Atlantic ocean. Fish Res 209: 67-74.

Laxson CJ, Condon NE, Drazen JC, et al. 2011. Decreasing urea: trimethylamine $\mathrm{N}$-oxide ratios with depth in Chondrichthyes: A physiological depth limit? Physiol Biochem Zool 84 (5): 494-505.

Lea JSE, Humphries NE, Clarke CR, et al. 2015. To Madagascar and back: long-distance, return migration across open ocean by a pregnant female bull shark Carcharhinus leucas. J Fish Biol 87 (6): 13131321.

Lucifora LO, de Carvalho MR, Kyne PM, et al. 2015. Freshwater sharks and rays. Curr Biol 25 (20): R971-R973.

Lucifora LO, García VB, Worm B. 2011. Global diversity hotspots and conservation priorities for sharks. PLoS ONE 6: e19356. DOI: 10.1371/journal.pone.0019356.

Martin RA. 2005. Conservation of freshwater and euryhaline elasmobranchs:a review. J Mar Biol Assoc UK 85: 1049-1073.

Matich P, Heithaus MR. 2012. Effects of an extreme temperature event on the behavior and age structure of an estuarine top predator Carcharhinus leucas. Mar Ecol Prog Ser 447: 165-178.

McCord ME, Lamberth SJ. 2009. Catching and tracking the world's largest Zambezi (bull) shark Carcharhinus leucas in the Breede Estuary, South Africa: the first 43 hours. African J Mar Sci 31 (1) 107-111.

Md-Zain BM, Abid-Kamal SNA, Aifat NR et al. 2018. Molecular identification of shark fins in Malaysian Borneo's local markets. Biodiversitas 19: 1035-1043.

Metcalfe JD, Craig JF. 2011. Ethical justification for the use and treatment of fishes in research: an update. J Fish Biol 78 (2): 393-394.

Midway SR, Wagner T, Burgess GH. 2019. Trends in global shark attacks. PLoS ONE 14(2): e0211049. DOI: 10.1371/journal.pone.0211049

Myers GS. 1952. Sharks and sawfishes of the Amazon. Copeia 1952:268 269.

Naidoo G. 2016. The mangroves of South Africa: An ecophysiological review. South African J Botany 107: 101-113.

Nicolaus EEM, Bendall VA, Bolam TPC, et al. 2016. Concentrations of mercury and other trace elements in porbeagle shark Lamna nasus. Mar Poll Bull 112 (1-2): 406-410.

Niella YV, Afonso AS, Hazin FHV. 2017. Bioecology and movements of bull sharks, Carcharhinus leucas, caught in a long-term longline survey off northeastern Brazil. Neotrop Ichthyol 15 (3): e170106. DOI: 10.1590/1982-0224-20170106.

Nosal AP, Chao Y, Farrara JD, et al. 2016. Olfaction contributes to pelagic navigation in a coastal shark. PLoS ONE 11 (1): e0143758. DOI: 10.1371/journal.pone.0143758

O'Connell CP, Hyun S-Y, Gruber SH, et al. 2014. The use of permanent magnets to reduce elasmobranch encounter with a simulated beach net. 1. The bull shark (Carcharhinus leucas). Ocean Coast Manag 97: 12-19.

O'Connell M, Shepherd T, O'Connell A, et al. 2007. Long-term declines in two apex predators, bull sharks (Carcharhinus leucas) and alligator gar (Atractosteus spatula), in Lake Pontchartrain, an oligohaline estuary in southeastern Louisiana. Estuar Coast 30: 567-574.

Paighambari SY, Pouladi M, Parsa M. 2017. Seasonal relative abundance of fish larvae in Helleh River estuary (north of the Persian Gulf, Iran). Biodiversitas 18: 541-547.

Peel MC, Finlayson BL, McMahon TA. 2007. Updated world map of the Köppen-Geiger climate classification. Hydrol Earth Syst Sci 11 (5): 1633-1644.

Pillans RD, Franklin CE. 2004. Plasma osmolyte concentrations and rectal gland mass of bull sharks Carcharhinus leucas, captured along a salinity gradient. Compar Biochem Physiol A 138: 363-371.

Pillans RD, Fry GC, Steven ADL, et al. 2020. Environmental influences on long-term movement patterns of a euryhaline Elasmobranch (Carcharhinus leucas) within a subtropical estuary. Estuar Coast. DOI: $10.1007 / \mathrm{s} 12237-020-00755-8$.

Pirog A, Jaquemet S, Soria M, et al. 2015. First evidence of multiple paternity in the bull shark (Carcharhinus leucas). Mar Freshw Res. DOI: $10.1071 / \mathrm{mf} 15255$

Pirog A, Magalon H, Poirout T, Jaquemet S. 2019. Reproductive biology, multiple paternity and polyandry of the bull shark Carcharhinus leucas. J Fish Biol. DOI: 10.1111/jfb.14118.

Pistevos JCA, Nagelkerken I, Rossi T et al. 2015. Ocean acidification and global warming impair shark hunting behaviour and growth. Sci Rep 5 (1): 16293. DOI: 10.1038/srep16293.

Possamai B, Hoeinghaus DJ, Odebrecht C, et al. 2020. Freshwater inflow variability affects the relative importance of allochthonous sources for estuarine fishes. Estuar Coast 43: 880-893.

Potter IC, Warwick RM, Hall NG, et al. 2015. The physico-chemical characteristics, biota and fisheries of estuaries. Freshw Fish Ecol 48 79.

Reilly BD, Cramp RL, Wilson JM, et al. 2011. Branchial osmoregulation in the euryhaline bull shark, Carcharhinus leucas: a molecular analysis of ion transporters. J Exp Biol 214 (17): 2883-2895.

Rucinque DS, Souza APO, Molento CFM. 2017. Perception of fish sentience, welfare and humane slaughter by highly educated citizens of Bogotá, Colombia and Curitiba, Brazil. PLoS ONE 12 (1): e0168197. DOI: 10.1371/journal.pone.0168197.

Shuter JL, Broderick AC, Agnew DJ, et al. 2010. Conservation and management of migratory species. In: Milner-Gulland EJ, Fryxell J, Sinclair ARE (eds.), Animal Migration: A Synthesis. Oxford University Press, Oxford.

Simpfendorfer C, Burgess G.H. 2009. Carcharhinus leucas. The IUCN Red List of Threatened Species 2009: e.T39372A10187195.

Smoothey AF, Gray CA, Kennelly SJ, et al. 2016. Patterns of occurrence of sharks in sydney harbour, a large urbanised estuary. PLoS ONE 11 (1): e0146911. DOI: 10.1371/journal.pone.0146911.

Tan HH, Lim KKP. 1998. Freshwater elasmobranchs from the Batang Hari basin of Central Sumatra, Indonesia. Raffles Bull Zool 46: 425429.

Temple AJ, Kiszka JJ, Stead SM, et al. 2017. Marine megafauna interactions with small-scale fisheries in the southwestern Indian Ocean: a review of status and challenges for research and management. Rev Fish Biol Fish 28 (1): 89-115.

Thomas N, Lucas R, Bunting P, Hardy A, Rosenqvist A, Simard M. 2017. Distribution and drivers of global mangrove forest change, 19962010. PloS ONE 12 (6): e0179302. DOI: 10.1371/journal.pone.0179302.

Thomerson JE, Thorson TB, Hempel RL. 1977. The bull shark, Carcharhinus leucas, from the upper Mississippi River near Alton, Illinois. Copeia 1977: 166-168.

Thorson TB. 1971. Movement of bull sharks, Carcharhinus leucas, between Caribbean Sea and Lake Nicaragua demonstrated by tagging. Copeia 1971: 336-338.

Tillett BJ, Meekan MG, Field IC. 2014. Dietary overlap and partitioning among three sympatric carcharhinid sharks. Endang Sp Res 25: 283-293.

Wagner CM, Rice PH, Pease AP. 2013. First record of dicephalia in a bull shark Carcharhinus leucas (Chondrichthyes: Carcharhinidae) foetus from the Gulf of Mexico, U.S.A. J Fish Biol 82 (4): 1419-1422.

Werry JM, Clua E. 2013. Sex-based spatial segregation of adult bull sharks, Carcharhinus leucas, in the New Caledonian great lagoon. Aquat Living Res 26 (4): 281-288

Werry JM, Lee SY, Lemckert CJ, et al. 2012. Natural or artificial? habitatuse by the bull shark, Carcharhinus leucas. PLoS ONE 7 (11): e49796. DOI: 10.1371/journal.pone.0049796. 
Werry JM, Lee SY, Otway NM, Hu Y, Sumpton W. 2011. A multifaceted approach for quantifying the estuarine-nearshore transition in the life cycle of the bull shark, Carcharhinus leucas. Mar Freshw Res 62(12): 1421-1431.

Werry JM, Sumpton W, Otway NM, et al. 2018. Rainfall and sea surface temperature: key drivers for occurrence of bull shark, Carcharhinus leucas, in beach areas. Global Ecol Conserv 15: e00430. DOI 10.1016/j.gecco.2018.e00430.

West JG. 2011. Changing patterns of shark attacks in Australian waters. Mar Freshw Res 62 (6): 744-754
Wiley TR, Simpfendorfer CA. 2007. The ecology of elasmo-branches occurring in the Everglades National Park, Florida: implications for conservation and management. Bull Mar Sci 80: 171-189.

Yulianto I, Booth H, Ningtias P, et al. 2018. Practical measures for sustainable shark fisheries: Lessons learned from an Indonesian targeted shark fishery. PLoS ONE 13 (11): e0206437. DOI: 10.1371/journal.pone.0206437.

Zainudin IM, Patria MP, Rahardjo P, et al. 2017. Bycatch of sharks, marine mammals and seabirds in Indonesian Tuna Longline Fishery. Biodiversitas 18: 1179-1189. 